\title{
A New Fossil Amiid from the Eocene of Senegal and the Persistence of Extinct Marine Amiids after the Cretaceous-Paleogene Boundary
}

\author{
Author(s): Maureen A. O'Leary, Raphaël Sarr, Raymond Malou, El Hadji Sow , Chris Lepre , and
} Robert V. Hill

Source: Copeia, 2012(4):603-608. 2012.

Published By: The American Society of Ichthyologists and Herpetologists

DOI: http://dx.doi.org/10.1643/CI-11-130

URL: http://www.bioone.org/doi/full/10.1643/CI-11-130

BioOne (www.bioone.org) is a nonprofit, online aggregation of core research in the biological, ecological, and environmental sciences. BioOne provides a sustainable online platform for over 170 journals and books published by nonprofit societies, associations, museums, institutions, and presses.

Your use of this PDF, the BioOne Web site, and all posted and associated content indicates your acceptance of BioOne's Terms of Use, available at www.bioone.org/page/terms_of_use.

Usage of BioOne content is strictly limited to personal, educational, and non-commercial use. Commercial inquiries or rights and permissions requests should be directed to the individual publisher as copyright holder. 


\title{
A New Fossil Amiid from the Eocene of Senegal and the Persistence of Extinct Marine Amiids after the Cretaceous-Paleogene Boundary
}

\author{
Maureen A. O'Leary ${ }^{1}$, Raphaël Sarr ${ }^{2}$, Raymond Malou ${ }^{2}$, El Hadji Sow ${ }^{2}$, \\ Chris Lepre ${ }^{3}$, and Robert V. Hill ${ }^{4}$
}

\begin{abstract}
We report a new fossil amiid from Eocene rocks of West Africa representing the first record of this clade from Senegal. The new specimen has a maxilla that is very similar in size to that of Amia calva. It is distinctly smaller than reported remains of another West African Eocene taxon, †Maliamia gigas. We tentatively refer the Senegal specimen to Vidalamiini because it has the large postmaxillary process diagnostic of this clade; however, it also exhibits anatomical features not previously described in extinct amiids. We recovered the specimen in rocks of the Lam-Lam Formation in Central-Western Senegal that we interpret to have been a shallow marine depositional environment. The occurrence of an Eocene marine amiid contradicts existing hypotheses that marine amiids were generally absent after the CretaceousPaleogene boundary having been replaced by freshwater taxa. Research completed since the initial discovery of $\dagger$ Maliamia gigas indicates that this Eocene taxon was also found in shallow marine rocks.
\end{abstract}

\begin{abstract}
Nous avons découvert un poisson fossile dans les sédiments éocènes de l'Afrique de l'Ouest, le premier représentant du clade des Amiidae au Sénégal. Le nouveau fossile a presque la même taille que l'espèce actuelle, Amia calva. Le fossile sénégalais a une longue processus postmaxillaire diagnostique de Vidalamiini. Le fossile montre aussi plusieurs charactéristiques anatomiques qui n'ont jamais été décrites chez les Amiidés fossiles. Nous avons trouvé le fossile dans les sédiments de la Formation du Lam-Lam au Centre-Ouest du Sénégal, et nous les interprétons comme des sédiments marins. La découverte d'un amiidé dans les gisements éocènes marins contredit l'hypothèse selon laquelle on ne trouve plus d'amiidés marins au-dessus de la limite Crétacé-Paléogène et qu'ils ont été remplacés par les amiidés d'eau douce. Les travaux stratigraphiques menés depuis la découverte de †Maliamia gigas ont montré que cette espèce était aussi présente dans les gisements marins.
\end{abstract}

$\mathrm{M}$ ODERN amiid fishes consist of a single freshwater species (Amia calva, the Bowfin) but the fossil record demonstrates a much more diverse past for the clade. A number of Mesozoic amiid fossils have been found in marine rocks, and many of these taxa have been interpreted to have inhabited marine environments (Grande and Bemis, 1998). Hypotheses as to when members of Amiidae ended a marine lifestyle and how this change relates to larger evolutionary or geological events must be pieced together from careful study of amiid fossils.

Only three extinct amiid taxa have been reported from Africa (Grande and Bemis, 1998). Two of these, †Maliamia gigas and †Calamopleurus africanus, are members of the clades Vidalamiinae and Calamopleuriini (Grande and Bemis, 1998). †Maliamia gigas, a very large-bodied species, is known from the Eocene of Mali, from rocks previously reported to be of indeterminate depositional environment (Patterson and Longbottom [1989], but see Discussion). $\dagger$ Calamopleurus africanus comes from Early Cretaceous rocks of Morocco (Forey and Grande, 1998) interpreted to be freshwater deposits. The third known African amiid ("†Uro-

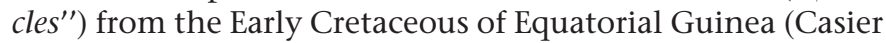
and Taverne, 1971) was declared a nomen dubium by Grande and Bemis (1998) for its lack of diagnostic characters.

Here we report our discovery of a new fossil amiid specimen from the Eocene of Senegal; we describe its geological context (Fig. 1), including paleoenvironment, and discuss the implications of this discovery for the overall interpretation of the marine-to-freshwater transition in Amiidae.

\section{MATERIALS AND METHODS}

Symbolic codes for institutions cited are: AMNH, Department of Ichthyology, American Museum of Natural History, New York, USA; CAD-SBU, Cheikh Anta Diop-Stony Brook University collection in the Department of Anatomical Sciences, Stony Brook University, Stony Brook, New York, USA. The geologic section was prepared from primary fieldwork by the authors and subsequent comparisons with an unpublished well core (by R. Sarr). The authors themselves collected the fossil during a 2010 paleontological expedition. The specimen was extracted from matrix in the fossil preparation laboratory of the Department of Anatomical Sciences, Stony Brook University, New York. To remove the specimen we used buffered acetic acid followed by minimal mechanical preparation with a needle. Anatomical terminology follows Grande and Bemis (1998); we made anatomical comparisons with the comprehensive published material in that volume and in Forey and Bemis (1998), as well as with the specimen Amia calva (AMNH 90970 SD). Daggers $(\dagger)$ indicate extinct taxa. SL $=$ snout length.

\footnotetext{
${ }^{1}$ Department of Anatomical Sciences, HSC T-8 (040), Stony Brook University, Stony Brook, New York 11794-8081; E-mail: maureen.oleary@ stonybrook.edu. Send reprint requests to this address.

${ }^{2}$ Département de Géologie, Faculté des Sciences et Techniques, Université Cheikh Anta Diop de Dakar, B. P. 5005 Dakar, Fann Sénégal; E-mail: (RS) rsarr@ucad.sn; (RM) malouraymond@yahoo.fr; and (EHS) elsow@ucad.sn.

${ }^{3}$ Department of Biology and Paleoenvironment, Lamont-Doherty Earth Observatory, 61 Route 9W, P.O. Box 1000, Palisades, New York 10964-8000; E-mail: lepre@ldeo.columbia.edu.

${ }^{4}$ Department of Anatomy, New York College of Osteopathic Medicine of New York Institute of Technology, Northern Boulevard, P.O. Box 8000, Old Westbury, New York 11568-8000; E-mail: rhill01@nyit.edu.

Submitted: 15 September 2011. Accepted: 5 July 2012. Associate Editor: W. L. Smith.

(c) 2012 by the American Society of Ichthyologists and Herpetologists DOI: 10.1643/CI-11-130
} 


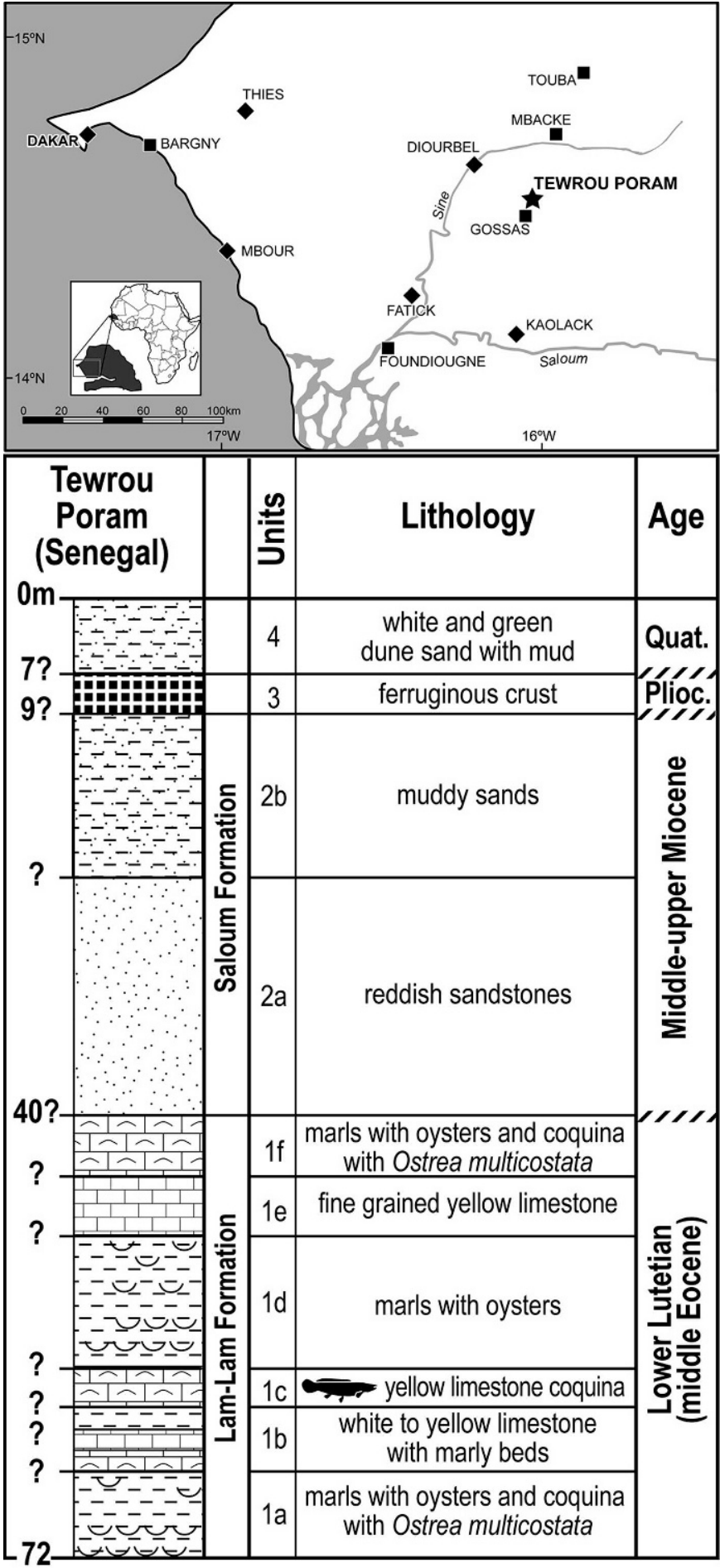

Fig. 1. Geographic location, Tewrou Poram, that yielded the fossil amiid and a composite section from the region. The amiid specimen came from level 1c of the lower Lutetian Lam-Lam Formation. The Saloum Formation lies unconformably on the Lam-Lam Formation. Units are separated by "?" because the thickness of these extremely hard-to-access layers can only be estimated. The oyster species noted is $\dagger$ Ostrea meunieri, an index fossil for the Lutetian of the Senegal basin.

Vidalamiini, incertae sedis

Figures 2-4

Diagnosis.-Members of Vidalamiini differing from other members of Vidalamiinae in possessing a thick and elongate postmaxillary process on the maxilla (Fig. $2 \mathrm{~A}$ ). anterior articular

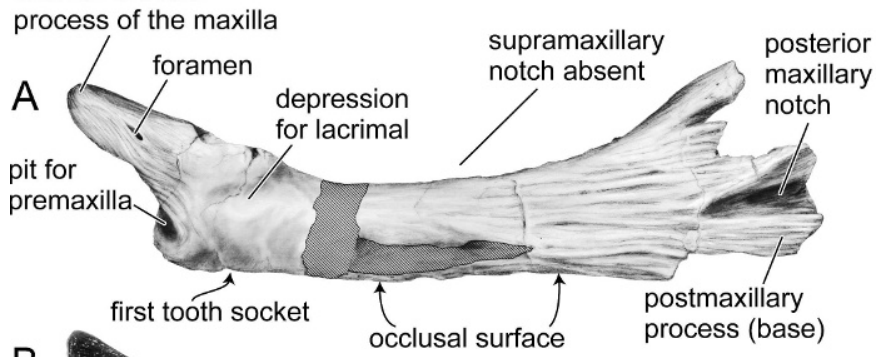

B
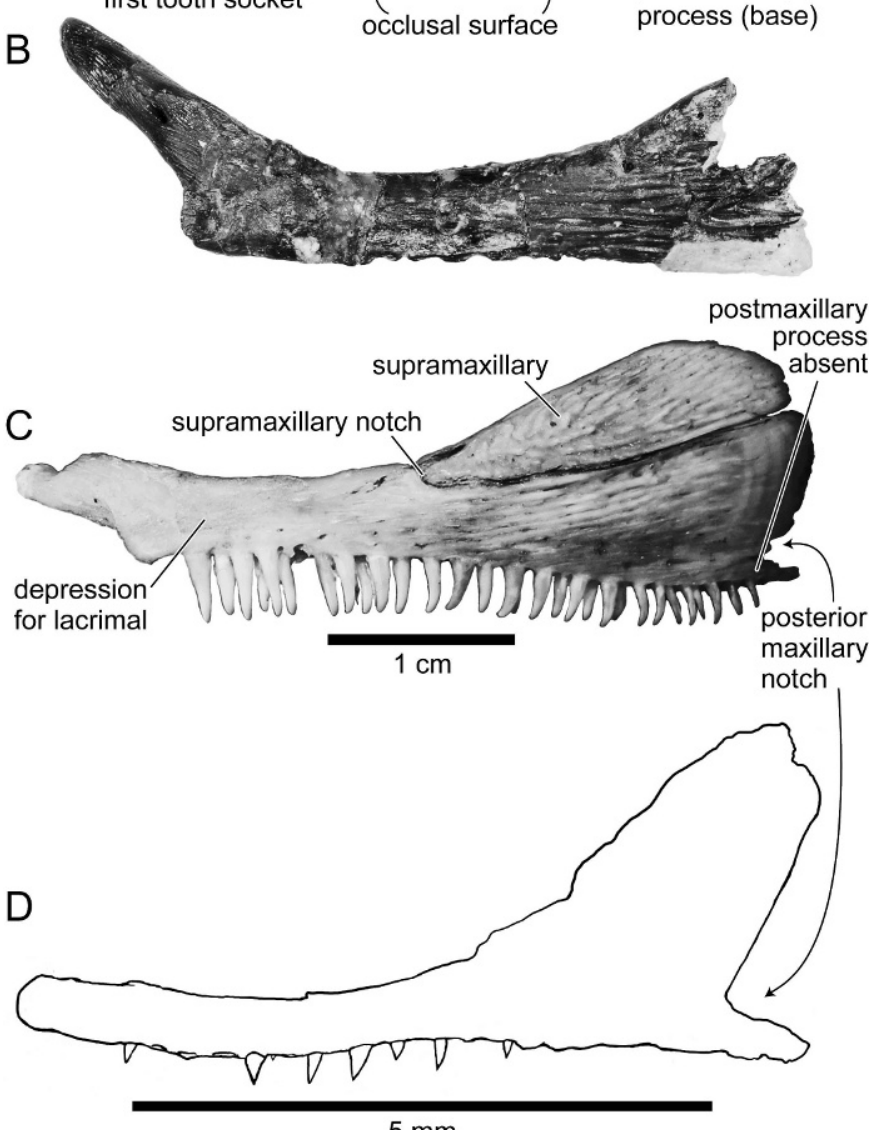

$5 \mathrm{~mm}$

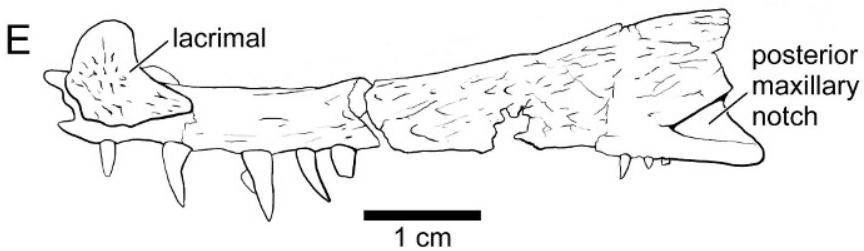

Fig. 2. Vidalamiini, incertae sedis, from the Eocene of Senegal (A-B) compared with Amia calva AMNH 90970 SD (C) and two extinct members of Vidalamiini, †Vidalamia catalunica ( $D$, redrawn from Grande and Bemis, 1998:fig. 253) and †Calamopleurus africanus ( $E$, redrawn from Forey and Grande, 1998:fig. 2). Left maxillae, lateral views. Scale bar $=1 \mathrm{~cm}$.

Non-type material.-CAD-SBU 1, from Paleogene rocks of the Lam-Lam Formation, Sine-Saloum region, Senegal.

Geological setting.-The new fossil comes from Paleogene rocks of the Sine-Saloum region of the central-western part of Senegal, approximately 200 kilometers east of Dakar (Fig. 1). Access to fossiliferous rocks is extremely rare in this region due to low elevation and significant coverage of Quaternary and Recent sand and alluvium. Older rocks are, however, brought to the surface on very rare occasions as a by-product of the construction of water wells. Drilling for several wells 


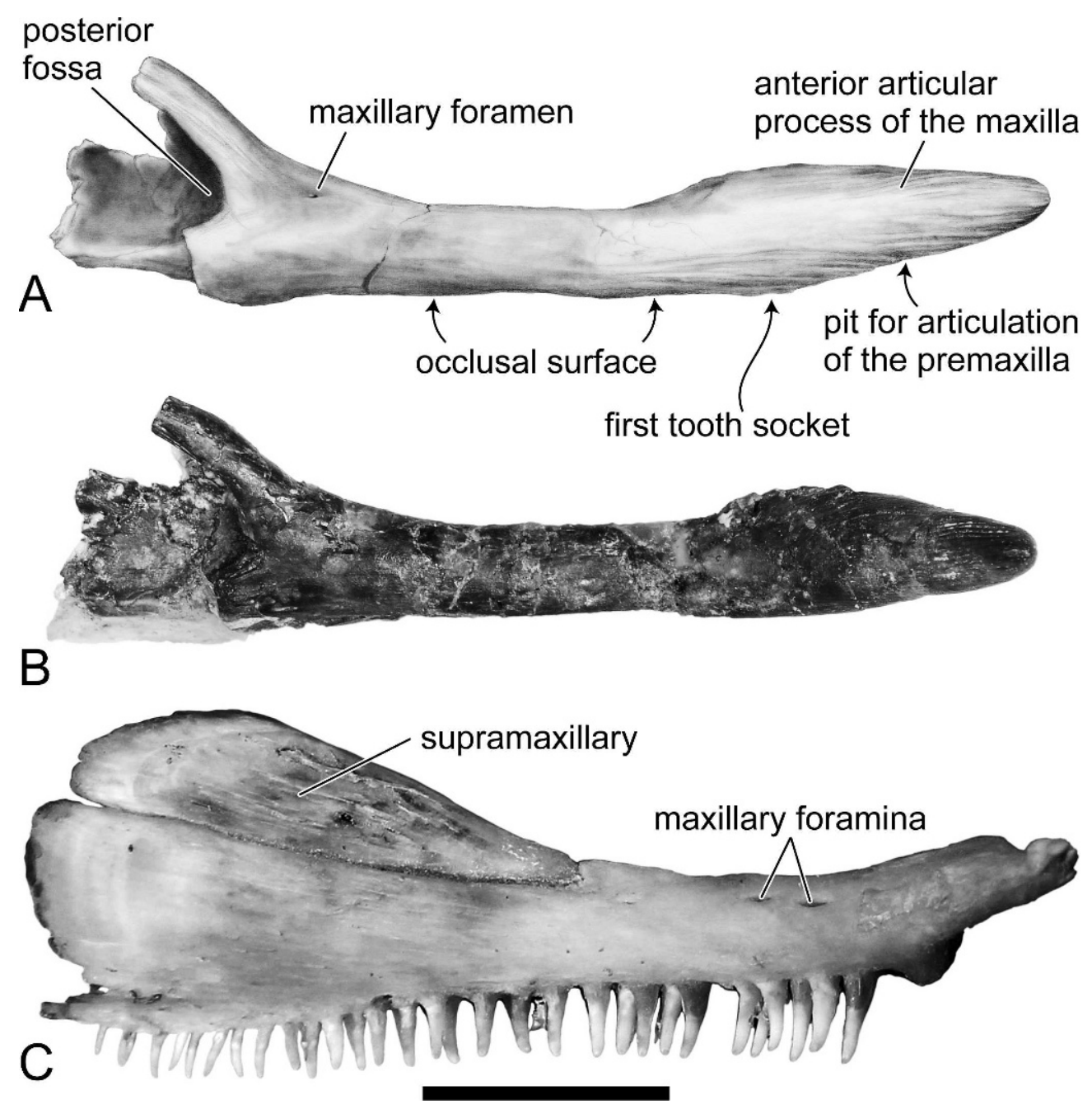

Fig. 3. Vidalamiini, incertae sedis, from the Eocene of Senegal (CAD-SBU-1; A-B) compared with Amia calva AMNH 90970 SD (C). Left maxillae in medial views. The large posterior fossa is absent in $A$. calva. Scale bar $=1 \mathrm{~cm}$.

has fortuitously yielded vertebrate fossils, the most noteworthy being the prior discovery of significant anatomical remains of an archaeocete cetacean (Élouard, 1966), now lost.

The fossil amiid locality is called Tewrou Poram (Senegal10) and is located near the town of Gossas (Fig. 1). It preserves the following rock sequence: lower Lutetian (middle Eocene) Lam-Lam Formation lying unconformably (Tessier, 1952; Lappartient, 1985) below the middle-upper Miocene Saloum Formation (initially designated as "Continental Terminal," see discussion in Tessier et al., 1975) followed, again, unconformably, by a Pliocene ferruginous crust lying under the Quaternary sands. The fossil comes from the Lam-Lam Formation, which generally consists of compact marls with oyster layers and limestone beds.

To develop the geological context for the Tewrou Poram fossil, we compared excavated rock samples with well logs from the drill core at the nearby town of Gossas (published in Tessier, 1952; the original core for Tewrou Poram is not preserved). We also compared index fossils in our sample to those in the Gossas core to create the Tewrou Poram section we present (Fig. 1). The age of the rocks is based on biostratigraphy of molluscs, nummulites, and echinoids (Tessier, 1952; Élouard, 1966; Monciardini, 1966), supplemented by that of planktonic foraminifera and ostracods (Sarr, 1995). In the well at Tewrou Poram, the Lam-Lam Formation rocks exhibit numerous coquina layers with †Ostrea meunieri, an index fossil for the Lower Lutetian of Senegal basin (Tessier, 1952; Freneix and Gorodiski, 1963).

The well, drilled by Caritas Kaolack in 2004, is $72 \mathrm{~m}$ deep (pers. comm. to R. Sarr by Caritas Kaolack) but relative thicknesses of different rocks represented at Tewrou Poram are unknown because the well core was not preserved. We have presented estimated thicknesses (Fig. 1) based on comparisons with the Gossas drill core (Tessier, 1952) and examination of the relative amounts of detritus surrounding the well. Subsurface rocks were distributed to a radius of approximately $100 \mathrm{~m}$ from the well. The fossil was embedded in the yellow limestone coquina of the Lam-Lam Formation collected within this radius.

A thin section of the rock that yielded the specimen indicates that the fossil came from an altered biosparite limestone with mixed chemical and clastic sedimentary textures-unit 1c in our section. Units $1 \mathrm{~b}$ and $1 \mathrm{e}$ are, by contrast, biomicrite.

Paleoenvironment.-We hypothesize that the lower Lutetian rocks at Tewrou Poram represent a range of shallow marine depositional environments on an internal platform (0-30 m depth) with littoral and lagunal conditions. Evidence for this hypothesis derives from the accumulation of fossil oysters in several units noted in our section as well as Tessier's (1952) discussion of marine molluscs, echinoids, 


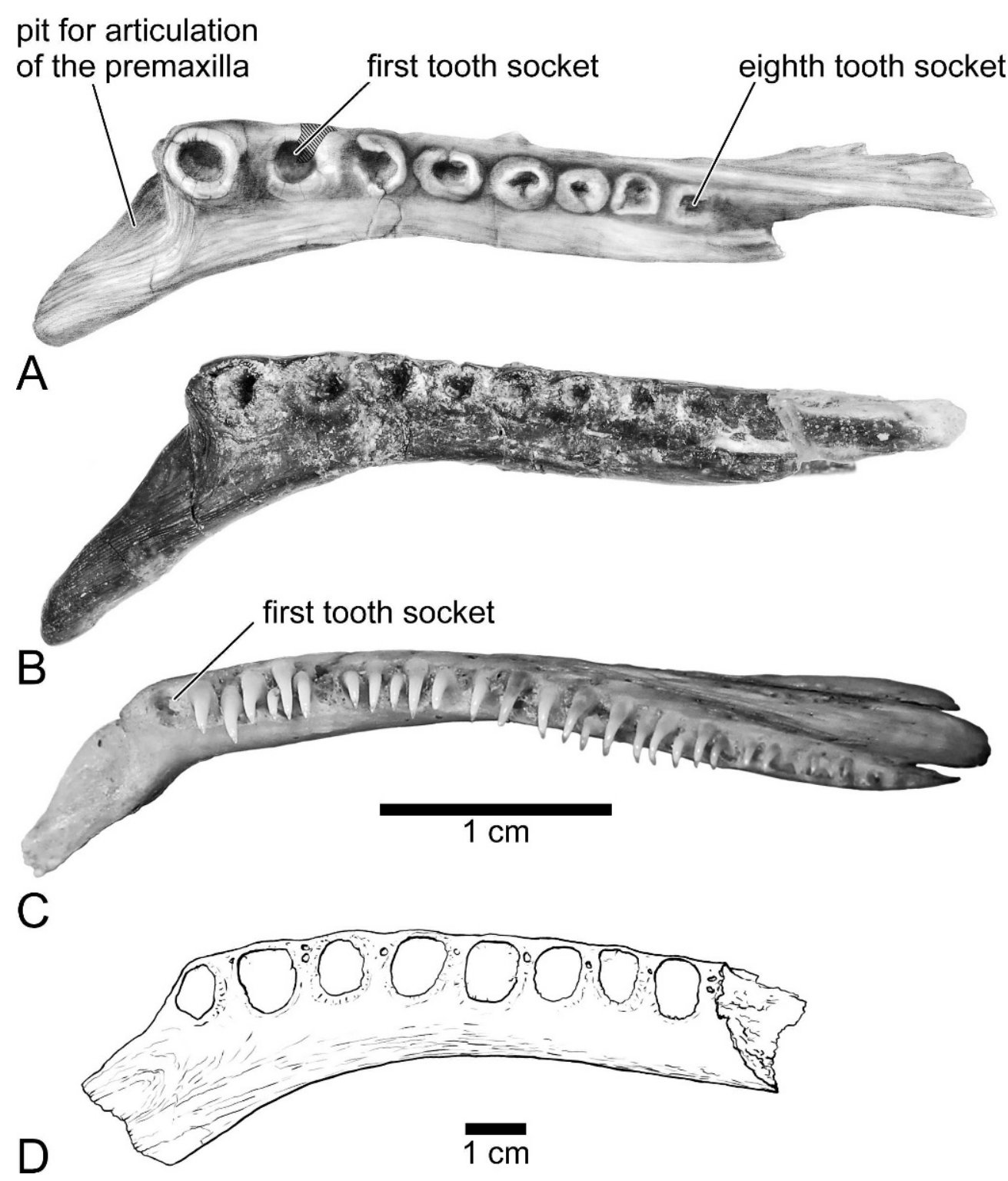

Fig. 4. Vidalamiini, incertae sedis, from the Eocene of Senegal (CAD-SBU-1; A-B) compared with Amia calva AMNH 90970 SD (C) and with $\dagger$ Maliamia gigas (redrawn from Grande and Bemis, 1998:fig. 321). Left maxillae in ventral views. Scale bar $=1 \mathrm{~cm}$.

and bryozoans in the Lam-Lam Formation of the Thiès and Sine-Saloum areas of Senegal. The overlying middle-upper Miocene Saloum Formation represents a range of possible shallow marine environments on a shallow carbonate platform, characterized by littoral conditions in a lagoonal setting (Tessier et al., 1975; Lappartient, 1985). The Pliocene ferruginous crust represents an ancient surface of erosion that was probably exposed to subaerial tropical (humid) conditions.

Description.-The fossil (CAD-SBU 1) consists of the anterior portion of a left maxilla including the tooth-bearing portion (Figs. 2-4) with the first through eighth tooth sockets (preservation of socket morphology becomes more ambiguous posteriorly). Preservation of the bone is excellent, and the intact surface texture exhibits "longitudinal ridges of ornamentation" on the lateral surface of the maxilla, as described for other amiids (Grande and Bemis, 1998:84). We have identified the fossil as an amiid because the shapes of the maxilla and tooth sockets resemble those of other living and extinct amiids, and there is evidence of a postmaxillary notch (although not fully preserved), a structure present in all Amiidae (Grande and Bemis, 1998).
More specifically, we refer it to the Vidalamiini because it possesses the postmaxillary process that diagnoses this clade.

The maxilla has a prominent anterior articular process that forms a distinct pointed prong angled approximately $45^{\circ}$ medially to the tooth-bearing part of the bone (Fig. 2). The anterior tip of the process is a gently blunted, intact articular surface and likely would have served as a pivot for movement of the maxilla (Lauder, 1980; see also discussion in Grande and Bemis, 1998:84). Along the anterior articular process is a small, oval foramen that opens anteriorly and slightly ventrally. The function of this foramen is unknown as it is not present in other amiids. Posterior to the foramen is a distinct pit for articulation of the premaxilla. The tooth sockets are aligned in a straight row and decrease in size posteriorly (Fig. 4). They are encircled by a raised, crenulated ridge (most pronounced at the anteriormost socket). This ridge does not appear to be striated per se (a feature of some amiid tooth sockets noted by Patterson and Longbottom [1989]). The maxilla is widest medially adjacent to the first tooth socket (Fig. 4).

The maxilla has a shallow depression for articulation with the lacrimal and possibly also the subinfraorbitals (although 
distinction between these articular surfaces is not apparent). Posteriorly the bone increases in height and lacks any indication of a supramaxillary notch. The posterior end of this maxilla is partially broken but its lateral surface has a clearly defined triangular fossa (Fig. 2A). At the inferior edge of this fossa is the base of a postmaxillary process (Grande and Bemis, 1998:573, see also fig. 243; note, these authors also call this a 'posterior process' [p. 339]). A very large postmaxillary notch invaginates the distal end of the maxilla and also continues onto the corpus of the maxilla as a fossa (compare figs. 243, 252, and 276 in Grande and Bemis [1998]). Preservation is too poor to determine how deeply the postmaxillary notch was set off from the rest of the bone.

In medial view, there is a single maxillary foramen positioned relatively posteriorly. The posterior part of the bone has a very large, well-defined fossa (Fig. 3A-B) that appears to be unnamed in Grande and Bemis (1998). It is set off by robust crests at the superior and inferior margins. We refer to it as the posterior fossa of the maxilla. This is approximately the region for articulation with the ectopterygoid. This fossa may have been the site of insertion of the adductor mandibulae muscle, in particular its anterior (suborbital) portion (Allis, 1897; Lauder, 1982:fig. 2]).

The Senegal specimen can be scored for four of the 69 phylogenetic characters identified by Grande and Bemis (1998:573): (30) "postmaxillary process under postmaxillary notch": "thick and elongate" (p. 580), state 1 (Fig. 2); (53) "shape of maxilla extremely slender and rod-like": "no" (p. 584), state 1 (Figs. 2-4); (60) "presence, absence of lateral line canal in maxilla": "absent" (p. 585), state 0 (Fig. 2); and (62) "shape of posterior margin of maxilla": "excavated, concave or with a posterior maxillary notch present" (p. 586), state 1 (Fig. 2). In their comprehensive revision of Amiidae, Grande and Bemis (1998) concluded that many fragmentary fossil amiid taxa contained no diagnostic apomorphies and were thus nomina dubia, even though these specimens constituted important records of the past history of the clade. This fragmentary specimen from Senegal also appears to lack autapomorphies that would make it a new species and we do not, therefore, name it or analyze it cladistically. We also cannot eliminate the possibility that the Senegal specimen is an ontogenetic variant of one of the already named African amiids. Of the few characters listed above that can currently be assessed in the Senegal specimen, most are primitive for Amiidae (Grande and Bemis, 1998). The presence of a postmaxillary process (Grande and Bemis,1998:character 30), however, is a synapomorphy of the clade Vidalamiini within Amiidae, and provides the only information about more specific affinities of the Senegal specimen.

Measurements: Anterior tooth socket diameter: $4 \mathrm{~mm}$; height of maxilla at base of articular process: $5 \mathrm{~mm}$.

Comparisons.-The maxilla described here is very close in overall size to the maxilla of Amia calva (AMNH 90970; 450 mm SL, Grande and Bemis, 1998:fig. 42), including direct comparisons of the size of the first tooth socket (Fig. 4). As in A. calva, the teeth and tooth sockets decrease in size from anterior to posterior; however, the teeth in the Senegal specimen appear to have been relatively larger and less numerous over an equivalent area than those in $A$. calva. Both A. calva and the specimen described here have longitudinal ornamental ridges on the lateral surface of the maxilla (Fig. 2), and in both taxa the articulation for the lacrimal is an elongate shallow fossa. The Senegal specimen differs in having a relatively more elongate and pointed anterior articular process of the maxilla (Fig. 2). Both the Senegal specimen and A. calva have distinct pits of similar absolute size for articulation with the premaxilla. In the Senegal specimen, however, the anterior articular process continues well anterior to this pit, terminating in a distinct prong. In A. calva, the anterior articular process terminates more abruptly. Amia calva also lacks a foramen on the lateral side of the anterior articular process; $A$. calva has two maxillary foramina on the medial side positioned relatively anteriorly, whereas the Senegal specimen has only one, and it is positioned relatively posteriorly (Fig. 3). The toothbearing portion of the maxilla in the Senegal specimen has a straighter shape from anterior to posterior (Fig. 4) than does the maxilla of $A$. calva. In ventral view (Fig. 4), the maxilla is thicker in the Senegal specimen (i.e., there is more bone medial to the first tooth socket than in $A$. calva). Articular surfaces for the premaxilla and lacrimal (and possibly the subinfraorbitals) have been noted in the fossil and are also distinct in A. calva.

Several important differences exist between the Senegal specimen and $A$. calva, such as the lack of postmaxillary process in A. calva. By contrast, †Vidalamia and $\uparrow$ Pachyamia both have large postmaxillary processes ventral to the posterior maxillary notch (Grande and Bemis, 1998:580), as in the Senegal specimen. It also appears that the posterior maxillary notch would have been quite large in the Senegal specimen (although only partly preserved), unlike the relatively small and gracile notch in $A$. calva (Fig. 2). The posterior part of the medial surface of the maxilla in A. calva is a flattened, thin, pan-like area (Fig. 3C), but in the Senegal specimen this area has a well-defined posterior fossa. The position of this fossa may reflect a difference in the type of articulation between the ectopterygoid and the maxilla. We have not seen an articulation like that of the Senegal specimen described in any taxon in the very comprehensive treatment of Amiidae by Grande and Bemis (1998) or in Forey and Grande (1998). This may be due in part to the chance fact that many amiid fossils, such as †Calampopleurus africanus (Forey and Grande, 1998), are preserved with the medial surface of the maxilla obscured. Finally, the Senegal specimen completely lacks a supramaxillary notch (preservation in this area is excellent) in contrast to the distinct notch in A. calva. We presently have no information to decide whether any of the differences, including size differences, may be attributed to ontogenetic variation in the Senegal specimen versus other taxa.

Of the three historic African discoveries, this new maxilla can only be compared directly with †Maliamia gigas (Patterson and Longbottom, 1989:fig. 5; Grande and Bemis, 1998:fig. 321C) and †Calamopleurus africanus (Forey and Grande, 1998:fig. 2; Grande and Bemis, 1998:fig. 435A). The Senegal amiid is dramatically smaller than $\uparrow$. gigas (Fig. 3) and more similar in size to $\uparrow C$. africanus (Fig. 2); however, as noted above, such differences could reflect ontogeny. The Senegal amiid shares with $\dagger C$. africanus a posterior maxillary notch that forms a fossa on the lateral side of the maxilla (Fig. 2). A hint of such a notch is visible in $\uparrow M$. gigas but this area is very poorly preserved. Forey and Grande (1998:185) noted that the maxilla of $\dagger C$. africanus closely resembled that of $\dagger C$. cylindricus. Like the Senegal specimen, both species of $\dagger$ Calamopleurus lack a pronounced supramaxillary notch, and no such notch appears in $†$ Maliamia gigas. The Senegal specimen and $\dagger C$. africanus both have ornamented striations on the lateral maxillae, a feature lacking in $\uparrow$. gigas according to Patterson and Longbottom (1989:831). The Senegal specimen and both African taxa have distinct pits for the premaxilla visible in lateral view. 
We tentatively conclude that this fossil represents a member of the clade Vidalamiini (as defined by Grande and Bemis, 1998:594) due to the shared presence of thick, elongate postmaxillary processes. Prior to our discovery, specimens of Vidalamiini had been known only from Cretaceous rocks, and this new specimen constitutes important new evidence that this clade survived the KPg extinction event. Furthermore, the geographic range of Vidalamiini has heretofore not been known to extend into Senegal.

\section{DISCUSSION}

Paleontological discoveries in ancient West African rocks can be particularly infrequent because of limited access to outcrops resulting from extensive sand coverage from the Sahara Desert. It is thus fortuitous that examination of rocks brought to the surface by water well construction has yielded new information on the evolution of Bowfin fishes. The new material described here exposes anatomical features not previously described in amiids, such as the distinct foramen on the anterior articular process of the maxilla and the large posterior fossa on the medial surface of the maxilla. We refrain from interpreting the soft tissues that might have been associated with these features, or the function of these features, given the fragmentary nature of the material.

As noted above, a transition from marine to freshwater environments occurred during the diversification of Amiidae. Grande and Bemis (1998:643) stated that "Most or all Cenozoic amiids appear to have lived in fresh water, while many or most Mesozoic amiids (and other halecomorphs) were probably marine" (at the time of their publication the habitat of $\uparrow$ Maliamia was considered unknown [Patterson and Longbottom, 1989:829]).

Based on the depositional environment of the new fossil presented here, it is most parsimonious, however, to conclude that this Paleogene amiid from Senegal was marine. Geologic research subsequent to Grande and Bemis (1998) has also shown that $†$ Maliamia came from shallow marine deposits (Tapanila et al., 2008, see also Tapanila et al., 2004; O'Leary et al., 2006; Hill et al., 2008) left by epeiric seas during transgressive episodes. Thus for the African Eocene taxa known to date, the hypothesis that a marine presence for amiids persisted well into the Paleogene must be considered. This means that amiid survivorship across the CretaceousPaleogene boundary was decoupled from a shift in habitat.

\section{ACKNOWLEDGMENTS}

V. Heisey prepared the fossils and L. Betti Nash prepared the illustrations. We thank K. Claeson, J. Conrad, L. Grande, N. Kley, E. Roberts, and M. Wilson for critical comments on the manuscript, and J. Sparks and R. Arrindel for access to comparative material. M. DePangher provided the petrographic analysis. We would like to thank the National Geographic Society, the National Science Foundation, the Research Foundation of the State University of New York at Stony Brook, and the Office of Research of the New York College of Osteopathic Medicine for supporting our work.

\section{LITERATURE CITED}

Allis, E. P. 1897. The cranial muscles and cranial and first spinal nerves in Amia calva. Journal of Morphology 12:487-808.

Casier, E., and L. Taverne. 1971. Note préliminaire sur le matériel paléoichthyologique éocrétacique récolté par la
Spanish Gulf Oil Compnay en Guinée équatoriale et au Gabon. Revue de Zoologie et de Botanique Africaines, Bruxelles 83:16-20.

Élouard, P. 1966. Découverte d'un Archéocète dans les environs de Kaolack. Notes Africaines 109:8-10.

Forey, P., and L. Grande. 1998. An African twin to the Brazilian Calamopleurus (Actinopterygii: Amiidae). Zoological Journal of the Linnean Society 123:179-195.

Freneix, S., and A. Gorodiski. 1963. Bivalves éocènes du Sénégal. Mémoires du Bureau de Recherches Géologiques et Minières 17:1-123.

Grande, L., and W. E. Bemis. 1998. A comprehensive phylogenetic study of amiid fishes (Amiidae) based on comparative skeletal anatomy. An empirical search for interconnected patterns of natural history. Journal of Vertebrate Paleontology Memoir 4:1-690.

Hill, R. V., J. A. McCartney, E. Roberts, M. Bouaré, F. Sissoko, and M. A. O'Leary. 2008. Dyrosaurid (Crocodyliformes: Mesoeucrocodylia) fossils from the Upper Cretaceous and Paleogene of Mali: implications for phylogeny and survivorship across the K/T Boundary. American Museum Novitates 3631:1-19.

Lappartient, J. R. 1985. Le Continental Terminal et le Pléistocène ancien du bassin sénégalo-mauritanien. Stratigraphie, sédimentation, diagenèse, altérations. Reconstitution des paléorivages au travers des cuirasses. Thèse Doctorat ès Sciences, Université Aix-Marseille.

Lauder, G. V. 1980. Evolution of the feeding mechanism in primitive actinopterygian fishes: a functional anatomical analysis of Polypterus, Lepisosteus and Amia. Journal of Morphology 163:283-317.

Lauder, G. V. 1982. Patterns of evolution in the feeding mechanics of actinopterygian fishes. American Zoologist 22:275-285.

Monciardini, C. 1966. La sédimentation éocène du Sénégal. Mémoire du Bureau de Recherches géologiques et Minières 43:1-65.

O'Leary, M. A., E. Roberts, M. Bouaré, F. Sissoko, and L. Tapanila. 2006. Malian Paenungulata (Mammalia: Placentalia): new African afrotheres from the Early Eocene. Journal of Vertebrate Paleontology 26:981-988.

Patterson, C., and A. E. Longbottom. 1989. An Eocene amiid fish from Mali, West Africa. Copeia 1989:827-836.

Sarr, R. 1995. Étude biostratigraphique et paléoenvironnementale des séries d'âge Crétacé terminal à Eocène moyen du Sénégal occidental. Systématique et migration des ostracodes. Thèse doctorat d'Etat ès Sciences, Université Cheikh Anta Diop, Dakar.

Tapanila, L., E. Roberts, M. Bouaré, F. Sissoko, and M. A. O'Leary. 2004. Bivalve borings in phosphatic coprolites and bone, Cretaceous-Paleogene, Northeastern Mali. Palaios 19:565-573.

Tapanila, L., E. Roberts, M. Bouaré, F. Sissoko, and M. A. O'Leary. 2008. Phosphate taxonomy of bone and coprolite conglomerates: a case study from the Eocene of Mali, NW Africa. Palaios 23:139-152.

Tessier, F. 1952. Contribution à la stratigraphie et à la paléontologie de la partie ouest du Sénégal (Crétacé et Tertiaire). Bulletin de la Direction des Mines de l'Afrique Occidentale Française, Dakar 14:1-570.

Tessier, F., R. Flicoteaux, J.-R. Lappartient, D. Nahon, and J.M. Triat. 1975. Reform of the concept of "Continental Terminal" in the coastal sedimentary basins of West Africa. Travaux des Laboratoires des Sciences de la Terre, SaintJérôme, Marseille, Série A 8:1-6. 